MAGDALENA SMOLEŃ-WAWRZUSISZYN

Katolicki Uniwersytet Lubelski Jana Pawła II https://orcid.org/0000-0002-7886-5894
Copyright and License: Copyright by Instytut Języka Polskiego PAN, Kraków 2021. This article is published under the terms of the Creative Commons Attribution - NoDerivatives 4.0 International (CC BY- ND 4.0) License (https:// creativecommons.org/licenses/by-nd/4.0/legalcode.pl).

\title{
BIZNESWOMAN, BIZNESMENKA, KOBIETA BIZNESU, PRZEDSIĘBIORCZYNI CZY KOBIETA PRZEDSIĘBIORCZA? NAZEWNICTWO KOBIET ZWIĄZANYCH Z BIZNESEM WE WSPÓŁCZESNYM DYSKURSIE PUBLICZNYM
}

Słowa kluczowe: osobowe nazwy żeńskie, feminatywum, anglicyzm, praktyki nominacyjne, kobiety w biznesie, dyskurs publiczny.

\section{STRESZCZENIE}

Przedmiotem artykułu jest analiza wariantywnych jednostek nazewniczych występujących we współczesnym dyskursie publicznym i odnoszących się do kobiet działających w biznesie. Celem analiz jest wyjaśnienie przyczyn istniejącej wariancji w perspektywie językowej (systemowo-stylistycznej) i pozajęzykowej (polityczno-społeczno-kulturowej). Badania kontekstów funkcjonowania analizowanych jednostek przeprowadzono na materiale pozyskanym z kwerend słownikowo-korpusowych oraz z ekscerpcji własnej. Ze względu na dyskursywne uwikłanie osobowych nazw żeńskich osobnej weryfikacji poddano narracje komunikacyjne środowisk kobiecych. Przedstawiona dyskusja skłania do następujących wniosków: 1) obecna w dyskursie publicznym wariantywność analizowanych jednostek jest efektem przemian w języku i komunikacji uwarunkowanych czynnikami kulturowo-społecznymi po przełomie 1989 roku oraz po przyłączeniu Polski do UE w 2004 roku; 2) istniejące nazewnicze rozwiązania alternatywne to wynik zarówno różnych typów i etapów procesu adaptacji anglicyzmu businesswoman w polszczyźnie przy jednoczesnej konkurencji ze strony rodzimych form, jak i sprzężenia tych zjawisk ze zmianami komunikacji kobiecych środowisk biznesowych; 3) wybory nazewnicze mają uzasadnienie stylistyczne i dyskursywne; 4) najnowsza w badanym zbiorze jednostka kobieta przedsiębiorcza staje się jedną z językowych manifestacji biznesowej emancypacji Polek.

\section{WPROWADZENIE}

\section{I.1. Cel i metoda badań}

Inspiracją do podjęcia niniejszych rozważań było zaobserwowanie we współczesnym dyskursie publicznym wariantywności w odniesieniu do żeńskich nazw osobowych będących tekstowymi reprezentacjami nazw kobiet zajmujących się biznesem. Chodzi tu o takie jednostki, jak bizneswoman, biznesmenka, przedsiębiorczyni, kobieta biznesu, 
kobieta interesu czy kobieta przedsiębiorcza. Wskazana różnorodność nazewnicza nasuwa pytania o jej uwarunkowania, zwłaszcza że świat biznesu i obecność w nim kobiet w polskiej rzeczywistości podlegały stopniowej adaptacji realiów Zachodu w rezultacie przełomowych wydarzeń polityczno-gospodarczych. Do nurtujących pytań w takim kontekście należą m.in. następujące kwestie: Czym spowodowana jest wskazana wariantywność? Jaki wpływ na nią miały przeobrażenia społeczno-kulturowe? Na ile istotne stają się tutaj mechanizmy tradycji nominacyjnej polszczyzny? Czy decydujące okazują się czynniki systemowe, czy też za rozstrzygające należy uznać praktyki komunikacyjnojęzykowe określonych środowisk lub nurtów dyskursywnych? Czy zebrane jednostki mają tożsamą wartość referencyjną? Weryfikacja tych zagadnień stanowi cel niniejszych rozważań.

Aby odpowiedzieć na postawione pytania, zaplanowano badania oparte na materiale wyekscerpowanym z dostępnych źródeł słownikowych i korpusowych oraz na materiale zbieranym samodzielnie. Wyjściowy zestaw nazw - jak już wspomniano - był efektem własnych obserwacji dyskursu publicznego. W celu pozyskania jak największej ilości kontekstów użycia interesujących nas jednostek oraz stworzenia różnoaspektowego przeglądu tych użyć - nie tylko z perspektywy stanu obecnego, lecz także z uwzględnieniem faktów komunikacyjnych go poprzedzających - przeprowadzono kwerendę tych jednostek w różnego typu zbiorach leksykalnych polszczyzny. Przyjęto następujące zbiory: 1) źródła leksykograficzne - słowniki ogólne języka polskiego, 2) źródła korpusowe: NKJP, Monco, Słowosieć, oraz 3) kompendium leksykalne Nowe słownictwo polskie pod redakcją Teresy Smółkowej. Aby zobrazować częstotliwość występowania analizowanych jednostek w określonym czasie, do każdego wyszukania zamieszczono w tabeli grafy i wskaźniki liczbowe z NKJP oraz Monco. Dzięki danym z NKJP można zapoznać się z funkcjonowaniem danej jednostki w okresie do 2010 roku, natomiast wykresy Monco wykazują najnowszy stan: dzienną częstość z ostatnich 3 miesięcy (datę raportu podano w tabeli) oraz tygodniową częstość z ostatnich 24 miesięcy.

W zakresie kwerendy własnej - poza śledzeniem ogólnego dyskursu publicznego osobnej weryfikacji poddano funkcjonowanie badanego nazewnictwa $w$ ramach praktyk komunikacyjnych kilku popularnych organizacji i portali związanych z biznesową aktywnością kobiet. Celem tego badania było sprawdzenie, czy wybory nazewnicze środowisk kobiecych odbiegają od tych, które są rejestrowane w pozostałych sferach komunikacji publicznej, i czy stanowią element jakiejś odrębnej narracji.

\section{2. Tło analiz}

2.1. Językowokomunikacyjne aspekty biznesu w kontekście społeczno-kulturowym

Działalność biznesowa oraz cechujący ją typ komunikacji specjalistycznej należą do wyrazistych zjawisk w polskich realiach po przełomie ustrojowym z 1989 roku. Nie bez związku z tym pozostaje spore zainteresowanie językoznawców językiem w biznesie / 
językiem biznesu ${ }^{1}$, chociaż - jak zauważa Paulina Gajda (2015) - język biznesu nie był w polszczyźnie odmianą, która powstała w efekcie przemian w latach 90 . XX wieku, ale konstytuowała się już znacznie wcześniej.

Prywatna działalność gospodarcza była w polskich realiach od początku przemian aktywnością społecznie pożądaną. Nie dziwi więc fakt, że słowo biznes, które i w potocznej, i w publicznej komunikacji stosowano jako - zazwyczaj nobilitujące - określenie prywatnych inicjatyw, szybko zaczęło przyjmować się w polszczyźnie². Do dziś, mimo rozpowszechnienia się spolszczonego wariantu tego zapożyczenia, za równoprawne normatywnie uznaje się dwie wersje zapisu: zarówno w anglojęzycznej postaci business, jak i w jej polskojęzycznej adaptacji biznes ${ }^{3}$. Definicja podana przez SJP PWN informuje, że biznes to „przedsięwzięcie handlowe lub produkcyjne przynoszące zysk; potocznie też: firma realizująca to przedsięwzięcie"”. Natomiast w WSJP wyróżniono już cztery kategorie znaczeniowe dla biznesu - „1) interes, 2) firma, 3) ludzie, 4) kierunek studiów" ", co dowodzi ekspansji i samego zjawiska, i jego językowego zakresu.

Realia społeczne po transformacji systemowej z 1989 roku przełożyły się też na nowe wzorce osobowe i zawodowe, w tym na wzorce bussinesmana oraz businesswoman jednoznacznie utożsamiane wówczas z modelem tzw. człowieka sukcesu (ekonomicznego). Jak zauważa Ewa Grzeszczyk, wzorzec człowieka sukcesu',

jednostki aktywnej, dynamicznej i zaradnej, skupionej przede wszystkim na karierze zawodowej i osiągającej dochody pozwalające na życie na odpowiednim poziomie: dom, samochód, egzotyczne wakacje, zakupy w markowych sklepach $(2003,10)$,

intensywnie upowszechniały polskie media lat 90 . Był to wówczas nowy, postulowany model społecznych aspiracji ${ }^{7}$.

\footnotetext{
${ }^{1}$ Zob. np. Arabski (1997), Cudak i Tambor (1996), Hącia (2010), Kochan (2010).

${ }^{2}$ Zdaniem Agnieszki Dominiak ,częstość występowania leksemu biznes w środkach masowego przekazu [...] potwierdza to, że wyraz ten stał się jednym ze słów kluczy w nowej polskiej rzeczywistości społeczno-politycznej po roku 1989" (2001, 26). Należy jednak pamiętać, że ten leksem funkcjonował już w polszczyźnie drugiej połowy XIX wieku: pierwszym słownikiem ogólnym języka polskiego, który notuje leksem business, jest SW (t. 1, 240).

${ }^{3}$ Zob. http://sjp.pwn.pl/szukaj/biznes.html (20 października 2019). Wariantywność zapisu przenosi się także na słowa tworzone na bazie tego leksemu i zaakceptowane w polszczyźnie w obu postaciach, np. biznesmen//businessman; bizneswoman//businesswoman.

${ }^{4}$ Tamże.

${ }^{5}$ Zob. https://www.wsjp.pl/index.php?id_hasla=13060\&ind=0\&w_szukaj=biznes (20 października 2019).

${ }^{6} \mathrm{~W}$ literaturze przedmiotu funkcjonuje też pojęcie język sukcesu. Tzw. język sukcesu uznaje się za swoisty kod (fenomen) lingwistyczno-kulturowy będący „[...] tworem epoki, w której właśnie sukces staje się ogólnie pożądaną wartością. To język codziennej komunikacji w dużych firmach, język szkoleń (treningów), kursów i poradników asertywności, korespondencji biznesowej, język listów motywacyjnych, ofert handlowych, ulotek i folderów promocyjnych" (Wolny-Peirs 2005, 8).

${ }^{7}$ Zwrócił na to uwagę także Mariusz Kwiatkowski. Jego zdaniem popularyzowanie i upowszechnianie się wzoru człowieka dążącego do sukcesu materialnego (ekonomicznego) było przejawem i efektem ,inwazji aksjologii rynkowej” (Kwiatkowski 2000, 136).
} 
Za kolejną istotną cezurę dla rozważanej kwestii należy uznać rok 2004 i wstąpienie Polski do Unii Europejskiej - ten fakt wpłynął znacząco również na postrzeganie roli kobiet w życiu publicznym (unijne postulaty równości płci we wszelkich sferach życia i na rynku pracy), w tym - na ich aktywizację zawodową, także biznesową, co musiało mieć swoje konsekwencje w zakresie zachowań nominacyjnych.

\section{2. Żeńskie nazwy osobowe w badaniach lingwistycznych}

Osobowe nazwy żeńskie - zwłaszcza zaś feminatywa - to zagadnienie, które ma już obszerną literaturę przedmiotu i w ciągu minionych 20 lat było analizowane zarówno w perspektywie systemowej (słowotwórczej), jak i pragmatyczno-kulturowej (lingwistyka płci, dyskursy feministyczne). Ten drugi nurt badań, powstały w związku z uaktywnieniem się dyskursów feministycznego i równościowego w polskim dyskursie publicznym, rozwija się szczególnie intensywnie w ostatniej dekadzie. Jak stwierdza Agnieszka Małocha-Krupa (2018, 11), ,nazwy żeńskie należą do takiej kategorii słowotwórczej, której twory są wyjątkowo mocno, wyraźnie i wielostronnie uwikłane w pajęczynę zależności polityczno-kulturowych".

W podjętych tu analizach uwzględniono dotychczasowe perspektywy rozważań oraz ustalenia literatury przedmiotu, zwłaszcza te przedstawione w opracowaniach monograficznych (Karwatowska i Szpyra-Kozłowska 2005; Łaziński 2006; Nowosad-Bakalarczyk 2009; Małocha-Krupa 2015, 2018). W zakresie ujęcia tematu i rozwiązań metodologicznych najważniejszy punkt odniesienia stanowi ostatnia z wymienionych publikacji, skupiona na wyjaśnianiu ,symbiotycznej zależności między feminatywum a them kulturowo-politycznym" (Małocha-Krupa 2018, 12). Autorka wskazanej tezy, w swoim obszernym materiałowo i zakresowo opracowaniu, nie była w stanie - po pierwsze - objąć (ani też nie było to jej celem) szczegółową refleksją tendencji rozwoju feminatywów w poszczególnych obszarach zawodowych, po drugie - swoją uwagę skupiła wyłącznie właśnie na formacjach feminatywnych, a nie na wszelkiego typu żeńskich jednostkach nazewniczych. Stąd za zasadny - także wobec wskazanych wyżej uwarunkowań społeczno-kulturowych - uznano ogląd zaobserwowanych nazw żeńskich dotyczących kobiet w biznesie. Moim celem nie jest tu pokazanie pełnego obrazu funkcjonowania każdej z odnotowanych jednostek, ponieważ wymagałoby to opracowania znacznie szerszego niż ramy jednego artykułu․ Prześledzenie praktyk nominacyjnych w sferze kobiecej aktywności w biznesie, na podstawie dostępnych danych leksykograficznych, korpusowych oraz własnych obserwacji, ma służyć charakterystyce pewnego etapu rozwoju tendencji nazewniczych, którego poświadczeniem jest stan współczesnego dyskursu publicznego.

\footnotetext{
${ }^{8} \mathrm{~W}$ prezentowanej analizie zostały pominięte jednostki dłuższe niż dwuskładnikowe typu kobieta sukcesu w biznesie, kobieta prowadzaca firmę/biznes, kobieta prowadzaca interesy itp.
} 


\section{DYSKUSJA}

Przedmiot badania stanowią zróżnicowane formalnie, ale nie dłuższe niż dwuelementowe nazwy feminatywne, które odnoszą się do kobiet zajmujących się biznesem czy też związanych z przedsiębiorczością i są używane jako odpowiedniki męskich nazw biznesmen/przedsiębiorca. Są to zarówno klasyczne feminatywa - rozumiane jako syntetyczne, jednowyrazowe reprezentacje tekstowe kategorii nomina feminativa zawierające morfologiczny wyznacznik żeńskości (Małocha-Krupa 2018, 12), jak i konstrukcje analityczne oparte na leksemie kobieta: kobieta przedsiębiorcza, kobieta biznesu / kobieta interesu. Poniżej omówiono je w podziale według tego kryterium formalnego. Osobnym punktem dyskusji jest analiza praktyk nazewniczych zaobserwowanych w kobiecych środowiskach biznesowych.

\section{1. Feminatywa}

\section{BIZNESWOMAN ${ }^{9}$}

Bizneswoman to symetryczny (jako anglicyzm) odpowiednik zapożyczenia biznesmen, które - jak wykazały badania Antoniny Grybosiowej - w latach 90. XX w. szybko stał się modnym zamiennikiem dla przedsiębiorcy: usunął starszy odpowiednik w cień, podobnie jak i inne jego wyrazy bliskoznaczne używane do tej pory (handlowiec, przemysłowiec) (Grybosiowa 2001, 66). Warto wspomnieć, że we współczesnej polszczyźnie ogólnej zakres definicyjny biznesmena w zasadzie pokrywa się ze znaczeniem przedsiębiorcy. W SJP PWN przedsiębiorca jest definiowany jako „właściciel przedsiębiorstwa"10. Natomiast biznesmen jest rozumiany jako ,1) człowiek prowadzący rozległe interesy 2) właściciel firmy handlowej, produkcyjnej lub usługowej"11.

Omawiany leksem odnotowano w NSP jako nowy wyraz w materiałach prasowych z lat 1993-2000 (2004, cz. 1, 72), przy czym podano jako równoważne dwa jego warianty, obrazujące kolejne etapy przyswajania angielskiego zapożyczenia: 1) zaimportowaną $\mathrm{z}$ angielszczyzny formę businesswoman z oryginalną pisownią, ale spolszczoną wymową, oraz 2) wariant bizneswoman, w którym nastąpiła graficzna adaptacja członu biznes.

Pojawienie się nazwy żeńskiej businesswoman/bizneswoman we wskazanym okresie oznaczało adaptowanie tego leksemu w polszczyźnie w okresie tożsamym dla procesu przyswajania biznesmena. Jak jednak wykazały badania Jolanty Piwowar, społeczny odbiór żeńskiego odpowiednika stał się nieco utrudniony:

mieliśmy [...] pewien problem z żeńskim odpowiednikiem słowa biznesmen [...], dość długo nie mogliśmy go zaakceptować. Do akcji włączyły się nawet media. Jedna z rozgłośni Polskiego Radia ogłosiła

\footnotetext{
${ }^{9}$ Bizneswoman nie jest feminatywem sensu stricto, ale włączam go tutaj jako jednostkę jednoelementową, w tym aspekcie tożsamą z pozostałymi jednostkami tej grupy, a odmienną od omawianych w kolejnej części konstrukcji analitycznych.

${ }^{10}$ Zob. http://sjp.pwn.pl/szukaj/przedsi\%C4\%99biorca.html (20 października 2019).

${ }^{11}$ Zob. http://sjp.pwn.pl/szukaj/biznesmen.html (20 października 2019).
} 
konkurs. Słuchacze zgłaszali propozycje słów mających zastąpić bizneswoman, jedną z wiodących propozycji była biznessa (utworzona na wzór słowa hostessa), jednak z czasem przekonaliśmy się do bizneswoman (2007-2008, 159).

Można przypuszczać, że te nominacyjne kontrowersje były odzwierciedleniem napięć światopoglądowych właściwych tamtemu okresowi wynikających ze zderzenia dotychczasowego postrzegania społecznej roli kobiet $\mathrm{z}$ modelem zachodnim. $\mathrm{Z}$ jednej strony dyskurs medialny dość intensywnie forsował wzór eleganckiej, robiącej karierę zawodową businesswoman, a z drugiej - w społecznej świadomości mocno jeszcze tkwił wizerunek matki Polki, której priorytetem były dotąd dom i rodzina (Balczyńska-Kosman 2011; Mandal 1994). Stąd nierzadko wzór kobiety sukcesu lansowany w polskich mediach był odbierany w latach 90 . bardziej krytycznie niż afirmacyjnie: jako karykaturalny obraz superkobiety (Grzeszczyk 2003, 264). Tyle że anglojęzyczne nazwy postrzegano jako prestiżowe, ,awansujące”, co okazywało się zgodne z ówczesną ogólną postawą entuzjastycznego stosunku do anglicyzmów. Poświadcza to cytat dokumentujący występowanie w latach 90. potocyzmu prywaciara, będącego pogardliwym określeniem właścicielki prywatnego sklepu lub zakładu:

Jeszcze niedawno biznesmenki, czy jak kto woli businesswomen, nazywano po prostu pogardliwie prywaciarkami, chociaż zazdroszczono im pieniędzy. Dziś nadal zazdrości im się ogromnych dochodów, ale honoruje je prestiżowymi tytułami (NSP 1993-2000, cz. 5, 81-82).

Bez wątpienia jednak potrzeba jednostki nominacyjnej dla kobiety związanej z biznesem była potrzebą nazewniczą początków lat 90. XX wieku (Dunaj 1993). Wówczas pojawiały się też próby tworzenia nazewniczych odpowiedników o hybrydowej naturze, z polskim ekwiwalentem dla ang. woman - przywołany wyżej tom NSP zamieszcza dwa przykłady synonimicznych okazjonalizmów bizneswoman: biznesdama oraz bizneskobieta $^{12}$.

W zbiorach NKJP wyszukiwarka odnajduje dla formy bizneswoman 120 kontekstów, zestawienie według daty wystąpienia wskazuje na pierwsze użycia w połowie lat 90 ., następnie odnotowuje intensywny wzrost wystąpień w pierwszej dekadzie XXI wieku oraz stałą obecność w kolejnych latach, chociaż z różnym wskaźnikiem częstotliwości. Te dane wydają się potwierdzać stopniowe akceptowanie tego wariantu zapożyczenia bezpośrednio po transformacji oraz jego przyswojenie i rozpowszechnienie w późniejszym okresie.

\footnotetext{
${ }^{12}$ Jak zaznacza Teresa Smółkowa w przedmowie do NSP, „okazjonalizmy uznajemy za warte pokazania wtedy, gdy są wyrazem potrzeb nazewniczych i są utworzone na podstawie produktywnych modeli słowotwórczych" (NSP 1993-2000, cz.1, 6).
} 
Tabela 1

Profile częstotliwości wystapień wg NKJP oraz Monco dla wyszukiwania bizneswoman

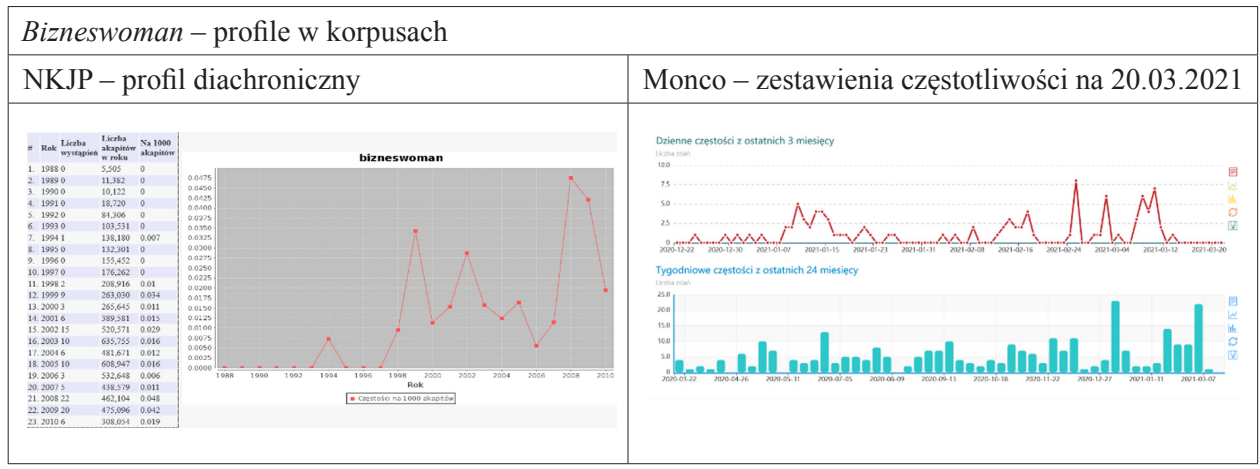

Rezultaty wyszukiwania w Monco - 4047 konkordancji - wykazały w zasadzie regularną i dużą częstotliwość występowania omawianej jednostki we współczesnym dyskursie medialnym, co pokrywa się z obserwacjami w materiale z ekscerpcji własnej.

Nazwa bizneswoman jest więc stale obecna od chwili jej przeniesienia na polski grunt, o ile jednak w latach 90. XX wieku była to nazwa wartościująca i wzbudzająca kontrowersje, o tyle obecne jest odbierana jako nazwa neutralna stylistycznie i pragmatycznie.

\section{BIZNESWOMANKA (BUSINESSWOMANKA) / BIZNESMENKA}

Bizneswomanka / businesswomanka to formacje oznaczone w NSP 1993-2000 (2004, cz.1, 72) jako wyrazy nowe w dokumentowanym okresie, natomiast w późniejszych leksykonach i korpusach te leksemy nie są notowane. Te formacje prawdopodobnie nie przyjęły się w powszechnym użyciu jako zbyt długie, jak również zbyt osobliwe graficznie i fonetycznie, a ich miejsce zajęła krótsza i wygodniejsza w wymowie biznesmenka, utworzona zgodnie z systemem według dominującego w polszczyźnie wzorca słowotwórczego dla nazw żeńskich: nazwa męska $+-k a$. Słowniki polszczyzny ogólnej nie interpretują statusu tego leksemu jednolicie, np. SJP PWN traktuje go neutralnie, z kolei WSJP przypisuje go już do rejestru stylu potocznego per analogiam do feminatywów typu dyrektorka, prezeska. Na podstawie danych korpusowych można jednak stwierdzić, że od początku potwierdzonych wystąpień było to feminatywum pojawiające się w dyskursie medialnym. W zbiorze PELCRA wyszukiwanie uwzględniające różne formy fleksyjne dla wyrazu biznesmenka dało 26 wyników w korpusie zrównoważonym, natomiast 99 w całym korpusie - w obu przypadkach większość kontekstów to źródła prasowe. Profile diachroniczne dla obu wariantów przeszukiwanego korpusu wskazują na względną regularność występowania biznesmenki w polszczyźnie. 
Tabela 2

Profile częstotliwości wystapień wg NKJP oraz Monco dla wyszukiwania biznesmenka**

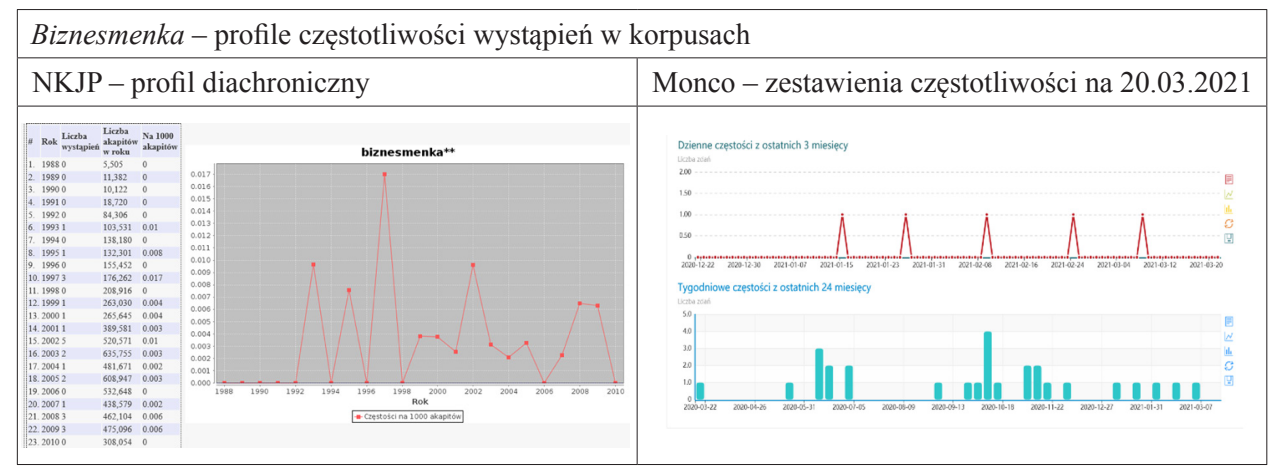

Dane z Monco (459 wystąpień), jak również ekscerpcja własna dyskursu medialnego z ostatnich kilku lat, potwierdzają stałą obecność omawianego feminatywum w przekazach medialnych przy w miarę zrównoważonej częstotliwości jego występowania w różnego typu portalach informacyjnych. Analiza kontekstów samodzielnie wynotowanych wskazuje na pewną tendencję do użycia biznesmenki w tytułach lub lidach, być może ze względu na ekspresywne (wynikające z uznania go za kolokwializm) zabarwienie tego wyrazu, choć np. Słowosieć nie przypisuje temu wyrazowi nacechowania emocjonalnego. Poniżej zamieszczono kilka przykładów wystąpienia omawianej formacji w takich kontekstach dyskursu medialnego pochodzących ze zbioru ekscerptów własnych:

(1) Polska biznesmenka to siłaczka, która już nie pada na twarz ${ }^{13}$.

(2) Biznesmenki $20+{ }^{14}$.

(3) Magdalena Witkiewicz, pisarka i biznesmenka z Gdańska, opowiada o swoich powieściach ${ }^{15}$.

(4) Matki Polki biznesmenki, czyli zamiast etatu własna firma ${ }^{16}$.

(5) Szansa dla biznesmenek z pomysłami ${ }^{17}$.

(6) Polskie biznesmenki są wielozadaniowe ${ }^{18}$.

${ }^{13}$ Zob. http://wyborcza.pl/magazyn/7,124059,23123891,polska-biznesmenka-to-silaczka-ktora-juz-nie-pada -na-twarz.html?disableRedirects=true (12 lutego 2019). Cytowania z materiału badawczego z ekscerpcji własnej oznaczam w artykule kolejnymi numerami.

${ }^{14}$ Zob. https://prestizkoszalin.pl/2019/02/biznesmenki-20/ (12 lutego 2019).

${ }^{15}$ Zob. https://dziennikbaltycki.pl/magdalena-witkiewicz-pisarka-i-biznesmenka-z-gdanska-opowiada -o-swoich-powiesciach/ar/709271 (30 października 2018).

${ }^{16}$ Zob. https://serwisy.gazetaprawna.pl/praca-i-kariera/artykuly/706262,matki-polki-biznesmenki-czyli -zamiast-etatu-wlasna-firma.html (1 grudnia 2018).

${ }^{17}$ Zob. https://www.pb.pl/szansa-dla-biznesmenek-z-pomyslami-955289 (4 maja 2019).

${ }_{18}$ Zob. https://media.bik.pl/informacje-prasowe/385609/bik-polskie-biznesmenki-sa-wielozadaniowe (29 marca 2018). 


\section{PRZEDSIĘBIORCZYNI}

Jest to feminatywum będące formacją regularnie derywowaną, tzn. utworzoną za pomocą sufiksu -yni od podstawy w rodzaju męskim zakończonej na -ca (przedsiębiorca). Jak dowodzi Małocha-Krupa, tego rodzaju proces nominacyjny - derywowanie feminatywów z sufiksem $i(y) n i$ od podstaw zakończonych na $-c a$, $-e k$, $-e c-$ był powszechny w XIX wieku, co dokumentuje prasa emancypacyjna tamtego okresu. Powrót do tych form stał się wyraźnie zauważalny w polszczyźnie ogólnej po 1989 roku (Małocha-Krupa 2018, 257) jako wyraz odradzania się kategorii feminatywum pod wpływem feministycznych koncepcji wyzwolenia przez język. W ten sposób, obok bizneswoman, polszczyzna od lat 90. XX wieku zyskała w rejestrze kolejną jednostkę nazewniczą odnoszącą się do kobiety związanej z biznesem. Jednak ówczesne praktyki komunikacyjne dowodzą, że $\mathrm{w}$ tamtym okresie leksem przedsiębiorczyni pozostawał na marginesie użyć w dyskursie publicznym. W NKJP ten leksem został potwierdzony tylko w ośmiu rekordach (cały korpus PELCRA), z czego pięć kontekstów to hasła z Wikipedii, a trzy to konteksty prasowe; wszystkie wystąpienia dotyczą okresu po 2000 roku. Można więc stwierdzić, że do 2010 roku rodzime feminatywum pozostawało właściwie bierną jednostką systemu, a stopniowej aktywizacji tego leksemu sprzyjały zmiany po 2004 roku. Propagowanie idei równościowych w polityce UE prowokowało do modyfikacji praktyk komunikacyjnych odpowiadających nowym regułom społecznym, co przekładało się także na dążenie do symetrii rodzimych jednostek nazewniczych: przykładem stał się również duet przedsiębiorca - przedsiębiorczyni. O silnym dążeniu do symetrii rodzajowo-płciowej w tym czasie pisze też Marta Nowosad-Bakalarczyk, zwracająca uwagę na fakt, że ta tendencja była bardziej wyrazista w odniesieniu do tytułów zawodowych niż do nazw służbowych, w których akceptowalne były formy męskie (2009, 149-151).

Tabela 3

Profile częstotliwości wystapień wg NKJP oraz Monco dla wyszukiwania przedsiębiorczyni

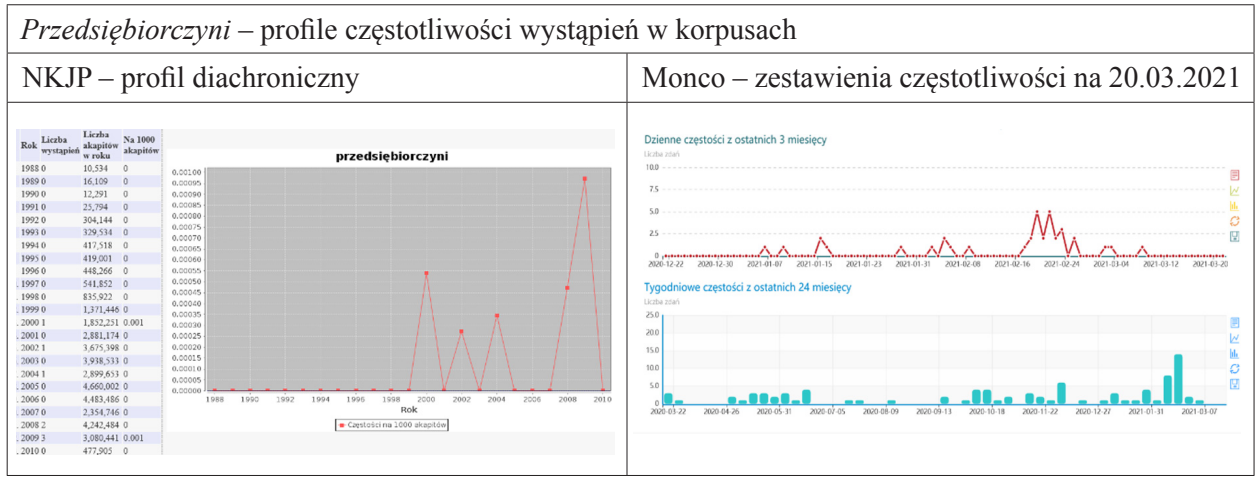

Na zmianę statusu przedsiębiorczyni we współczesnym dyskursie, zwłaszcza w ostatnich pięciu latach, wskazują dane z MONCO - uzyskujemy stamtąd 404 konkordancje. Zarówno rekordy wskazanej wyszukiwarki, jak i własna ekscerpcja źródeł internetowych 
dowodzą zróżnicowanej ekstensji tekstowej badanego feminatywum - pojawia się ono przede wszystkim w serwisach ekonomicznych czy prawniczych, rzadziej (ale również) w tekstach czy serwisach ogólnoinformacyjnych. Poniżej podano kilka przykładowych użyć w materiale z ekscerpcji własnej:

(7) Przedsiębiorczyni na urlopie wychowawczym musi opłacać składki ${ }^{19}$.

(8) ZUS zajął korzystne dla przedsiębiorczyni stanowisko, dokonał bowiem rozszerzającej, celowościowej wykładni usus, traktując świadczenie rodzicielskie jak zasiłek macierzyński (którym nie jest $)^{20}$.

(9) Przedsiębiorczynie społeczne rozprzestrzeniały innowacje poprzez tworzenie możliwości, by kobiety i dziewczęta widziały siebie nowych rolach - rolach liderek [... $]^{21}$.

(10) Martyna Sztaba, przedsiębiorczyni, Współzałożycielka i prezeska start-upu Syntoil, który zajmuje się pozyskiwaniem sadzy ze zużytych opon ${ }^{22}$.

(11) Symbolicznie, bo w okolicy Dnia Kobiet zorganizowane zostało spotkanie przeznaczone dla przedsiębiorczyń, które świadomie budują swoją karierę i z powodzeniem funkcjonują na mapie świdnickiego świata biznesu ${ }^{23}$.

(12) Polsat ma zakaz publikacji materiałów na temat zakopiańskiej przedsiębiorczyni ${ }^{24}$.

Poczynione obserwacje pozwalają na stwierdzenie, że po niemal dwóch dziesięcioleciach nominacyjnej dominacji w dyskursie publicznym nazwy zapożyczonej, w okresie słabnącego już napływu angielszczyzny, rodzime feminatywum zyskało swoją przestrzeń komunikacyjną. Najwcześniejsze wystąpienie, które notuje Monco, jest datowane na 2011 rok i pochodzi z serwisu bankier.pl - co też jest znamienne. Wydaje się przecież, że renesans tego leksemu w dyskursie publicznym nastąpił pierwotnie w tekstach specjalistycznych z zakresu ekonomii i stamtąd rozszerzył obszar swojego występowania na inne konteksty. Jednak to stwierdzenie pozostaje na razie w sferze hipotez, ponieważ nie przeprowadzono szczegółowych badań w tym zakresie.

\section{2. Nazwy analityczne}

Nazwy analityczne w badanym materiale mogą być postrzegane jako wyjątkowe zjawiska nominacyjne, jeśli wziąć pod uwagę fakt, że nie mają swojego źródła czy

${ }^{19}$ Zob. https://ksiegowosc.infor.pl/wiadomosci/128664,Przedsiebiorczyni-na-urlopie-wychowawczym-musi-oplacac-skladki.html (13 listopada 2019).

${ }^{20}$ Zob.https://rachunkowosc.com.pl/przedsiebiorczyni_na_swiadczeniu_rodzicielskim_zwolniona_od_ skladek_zus (13 listopada 2019).

${ }^{21}$ Zob. http://ashoka-cee.org/poland/2019/03/07/raport-celebrating-changemakhers-w-jaki-sposob-przedsiebiorczynie-spoleczne-przewodza-i-wprowadzaja-innowacje/ (13 listopada 2019).

${ }^{22}$ Zob. https://wyborcza.pl/Jutronauci/7,160052,25122215,martyna-sztaba.html (13 listopada 2019).

${ }^{23}$ Zob. http://um.swidnica.pl/pages/posts/kobiety-w-biznesie-ndash-relacja-ze-spotkania-dla-swidnickich-przedsiebiorczyn-2996.php (13 listopada 2019).

${ }^{24}$ Zob. https://m.podhale24.pl/aktualnosci/artykul/54186 (13 listopada 2019). 
pierwowzoru w męskich nazwach, gdzie - przypomnijmy - stosowanymi zamiennie jednostkami są biznesmen oraz przedsiębiorca. Ich wystąpienie uzasadnia jednak postępujący proces adaptacji angielskiego leksemu businesswoman, który jako złożenie dał podstawę do utworzenia kalk w postaci dwuelementowych jednostek nazewniczych.

\section{KOBIETA BIZNESU / KOBIETA INTERESU}

Powstanie form analitycznych było efektem poszukiwania najbardziej odpowiedniego - zarówno semantycznie, jak i formalnie - ekwiwalentu tłumaczeniowego w języku polskim dla angielskiego leksemu, który - jak wcześniej pokazano - przyjmował się do polszczyzny nieco opornie. Szansę na taki ekwiwalent dostrzeżono m.in. w utworzeniu zestawienia. Do Poradni Językowej PWN na początku 2009 roku wpłynęło następujące pytanie:

Jak najzgrabniej przetłumaczyć businesswoman? Czy można powiedzieć kobieta biznesu? Rozumiem, że istnieje w języku polskim słowo bizneswoman, ale wolałabym go uniknąćč

W odpowiedzi udzielonej przez eksperta PWN czytamy, że

można powiedzieć biznesmenka albo kobieta interesu. Wyrażenie kobieta biznesu jest nieco rzadsze i mniej tradycyjne, ale też spotykane, a czasem najlepsze, bo paralelne do innych, jakie łatwo utworzyć[,] por. ,[... ] są tam i kobiety biznesu, i kultury, i polityki, i mediów” (Henryka Bochniarz, Jacek Santorski, Bądź soba i wygraj: 10 podpowiedzi dla aktywnej kobiety ${ }^{26}$.

Formalnie zarówno kobieta biznesu, jak i kobieta interesu są kalkami angielskiego złożenia businesswoman, przy czym w pierwszym wariancie zachowano obcy wyraz, a w drugim wprowadzono jego zamiennik: interes - co pod względem stylistycznym skutkuje nie najzgrabniejszą frazą. Dane z wyszukiwań korpusowych skłaniają też do odmiennych - niż w powyższej opinii eksperta - konkluzji, gdyż potwierdzają od początku niską i malejącą z czasem akceptację dla frazy kobieta interesu. Poniżej znajdują się zestawienia profilowe dla każdego z omawianych przykładów.

\footnotetext{
${ }^{25}$ Zob. https://sjp.pwn.pl/poradnia/haslo/businesswoman;9811.html (20 października 2019). O przewadze kobiety interesu nad kobietą biznesu w materiale źródłowym (media) z 1992 roku i początków 1993 pisze Dunaj $(1993,169)$ - prawdopodobnie te dane badawcze stały się podstawą udzielonej odpowiedzi.

${ }^{26}$ Tamże.
} 
Tabela 4

Profile częstotliwości wystapień wg NKJP oraz Monco dla wyszukiwania kobieta** interesu

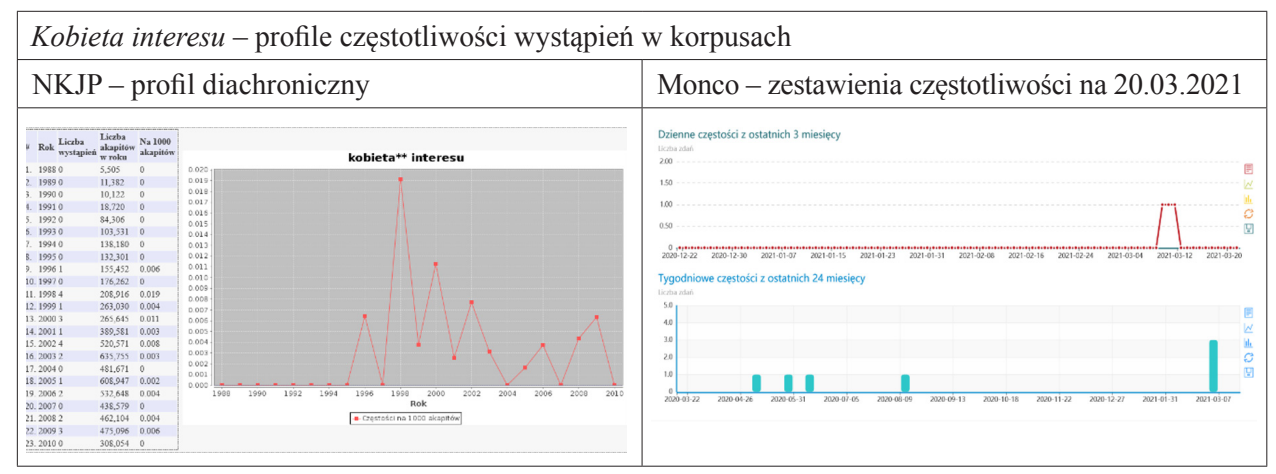

Tabela 5

Profile częstotliwości wystapień wg NKJP oraz Monco dla wyszukiwania kobieta** biznesu

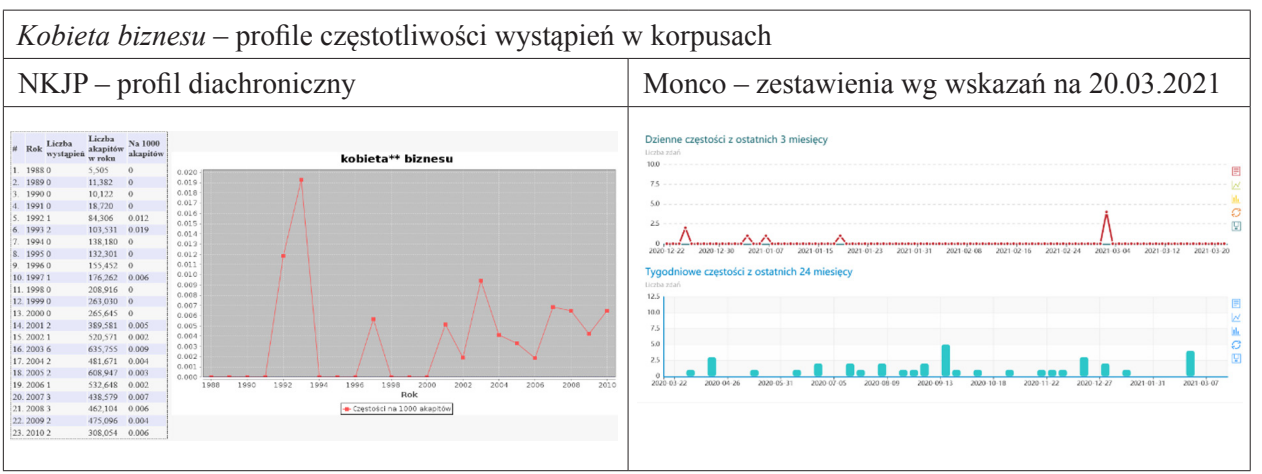

W NKJP mamy zbliżone rekordy dla obu jednostek: kobieta interesu - 24 wyników, kobieta biznesu - 28 wyników, czyli nieznacznie więcej, jednak na korzyść drugiej frazy. Poza tym pierwsze konteksty dla kobiety biznesu zarejestrowano wcześniej - w pierwszej połowie lat 90., a dla kobiety interesu dopiero w drugiej połowie tamtego dziesięciolecia. Po tym okresie frazą występującą do 2010 roku również okazuje się kobieta biznesu. Tę tendencję w praktykach nominacyjnych już zdecydowanie potwierdzają wyniki konkordancji w Monco, skąd dla kobiety interesu otrzymujemy 50 wyników, natomiast dla kobiety biznesu - 1290. Trzeba jednak zaznaczyć, że tak wysoki drugi wynik jest efektem obecnie już ponadziesięcioletniej tradycji corocznego plebiscytu na Kobietę Biznesu, o którym informacje są rozpowszechniane na wielu portalach. Porównanie wykresów częstości występowania każdej z tych nazw prowadzi do wniosku, że kobieta interesu jest obecnie frazą sporadyczną w dyskursie publicznym, natomiast kobieta biznesu - nazwą dominującą i pojawiającą się w miarę regularnie. 


\section{KOBIETA PRZEDSIĘBIORCZA}

Tabela 6

Profile częstotliwości wystapień wg NKJP oraz Monco dla wyszukiwania kobieta** przedsiębiorcza

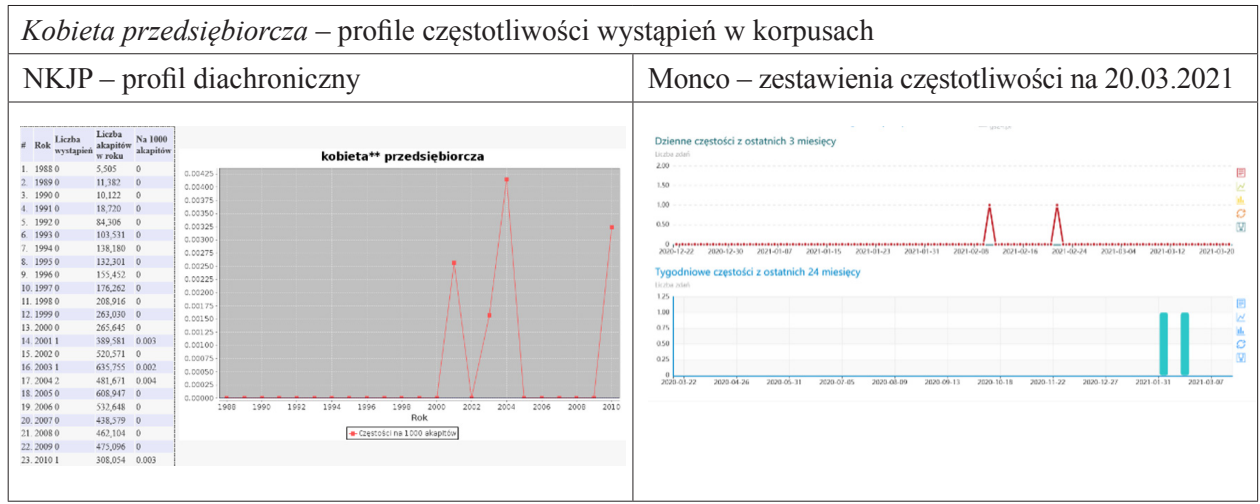

Powyższe dane korpusowe nie pozostawiają wątpliwości co do tego, że fraza kobieta przedsiębiorcza jest najnowszą jednostką w analizowanym zestawie żeńskich nazw osobowych, której pojawienie się w dyskursie publicznym można szacować na pierwszą dekadę XXI wieku. Z sześciu rekordów korpusu PELCRA cztery konteksty potwierdzają omawianą syntagmę jako nazwę własną - nazwę konkursu „Kobieta Przedsiębiorcza” organizowanego przez firmę kosmetyczną Avon. Jak można wnioskować z konkordancji wskazanych przez Monco, konkurs jest organizowany do dziś, przy czym w zmienionej formie - jako coroczny plebiscyt danego regionu (województwa, miasta), a nie - ogólnopolski i sponsorowany przez jedną firmę. Konkurs zyskuje z roku na rok coraz większy zasięg, co przekłada się na 1756 wyników wyszukiwania we wskazanym korpusie. Konteksty związane z plebiscytem nie są oczywiście wyłącznymi wystąpieniami tej frazy, ale na pewno zdecydowanie przeważającymi. Potwierdza to również wykres profilu częstotliwości, która kumuluje się w okresach ogłaszania rozpoczęcia konkursów, a następnie - ogłaszania ich wyników. W świetle tych danych można by omawianą frazę nazwać pewnego rodzaju nazwą okazjonalną we współczesnym dyskursie publicznym. Natomiast dominującymi wyborami nazewniczymi w odniesieniu do kobiet w biznesie pozostają w tej debacie bizneswoman lub jej częściowo spolszczony odpowiednik-kobieta biznesu.

\section{3. Praktyki komunikacyjne kobiecych środowisk biznesowych}

Aktywność kobiet w biznesie, która po roku 2004 znalazła wzmocnienie we wdrażanej u nas polityce gospodarczej Unii Europejskiej, stała się jednym z obszarów dających oparcie współczesnym dyskursom równościowym i narracjom je wyrażającym. Stąd decyzja o osobnym przyjrzeniu się w podjętych badaniach - bardziej jednak na zasadzie rekonesansu niż pełnego oglądu - praktykom komunikacyjnym kobiecych środowisk 
biznesowych skupionych wokół fundacji i portali internetowych. W narracji tych środowisk nie uderza celowe epatowanie określonymi jednostkami nazewniczymi, istotna dla jej wymowy staje się komunikacja skupiona na przedsiębiorczości i jej specyficznym rozumieniu w kobiecych kręgach.

Prężnie działającą organizacją biznesowych środowisk kobiecych jest fundacja Sukces Pisany Szminką (dalej: SPS), o której czytamy:

(13) Fundacja Sukcesu Pisanego Szminką jest najstarszą [działa od 2008 roku - M.S.W.] i największą organizacją w Polsce, której misją jest promowanie przedsiębiorczych postaw i kompleksowe wspieranie kobiet oraz młodzieży, dostarczanie im fachowej wiedzy niezbędnej do rozwoju osobistego i zawodowego oraz motywowanie ich do podejmowania odważnych działań i spełniania marzeńn ${ }^{27}$.

Aktualny zakres działań SPS obejmuje więc wsparcie nie tylko dla kobiet, lecz także młodzieży, w początkowych latach docelową grupą odbiorców były jedynie kobiety. Fundacja organizuje corocznie konkurs zatytułowany „Bizneswoman Roku”, pierwotnie skierowany wyłącznie do kobiet biznesu, z czasem rozszerzony o innego typu kategorie - kobiet wyróżniających się także w sferach społecznej, naukowej czy kulturalnej. W ramach prezentacji istoty działalności SPS twórczynie fundacji wyjaśniają:

(14) Sukces Pisany Szminką to społeczność kobiet, które wzajemnie uczą się i inspirują do działania, podejmowania odważnych decyzji i sięgania po więcej. Obojętnie, czy zarządzasz potężną firmą czy jesteś na początku drogi zawodowej i dopiero szukasz pomysłu na siebie, dziel się swoimi doświadczeniami, opowiadaj zarówno o swoich sukcesach, jak i wątpliwościach czy lękach. [...] Udowadniamy, że kobiecość jest atutem, a przedsiębiorczość kobiet jest kluczowym elementem w budowaniu silnej i stabilnej gospodarki ${ }^{28}$.

Inna ze znanych medialnie organizacji nosi znamienną nazwę Sieć Przedsiębiorczych Kobiet (dalej: SPK). Na jej stronie można się dowiedzieć, że:

(15) Misją Fundacji Przedsiębiorczości Kobiet jest propagowanie idei przedsiębiorczości wśród kobiet i wspieranie rozwoju firm prowadzonych przez kobiety oraz ich promocja. Fundacja nieustannie śledzi trendy i ewolucję rynku pracy i na podstawie wnikliwej analizy opracowuje programy i projekty, które są kompleksowym wsparciem dla kobiet młodych - wchodzących dopiero na rynek i tych planujących założenie własnego biznesu oraz tych, które już mają swoją działalność gospodarczą. Krótko mówiąc, fundacja pomaga wszystkim kobietom, które „przedsię-biorą”, czyli kierują własnym losem i decydują się na inicjowanie własnych działań.

Głównym celem Fundacji Przedsiębiorczości Kobiet jest przypomnienie kobietom, jak duży potencjał biznesowy w nich drzemie, jak sprawcze i samodzielne mogą i potrafią być - a to wszystko po to, by poznały smak spełnienia zawodowego. Przy czym Fundacja komunikuje również kobietom, że nie muszą robić wszystkiego same - razem stać je na dużo więcej, dlatego wspólnym mianownikiem wszystkich działań Fundacji Przedsiębiorczości Kobiet jest budowanie zawodowej społeczności kobiecej, której podstawą są takie wartości, jak solidarność oraz wzajemna pomoc i wsparcie ${ }^{29}$.

\footnotetext{
${ }^{27}$ Zob. https://sukcespisanyszminka.pl/fundacja/ (4 października 2020).

${ }^{28}$ Zob. https://sukcespisanyszminka.pl/o-nas/ (4 października 2020).

${ }^{29}$ Zob. https://siecprzedsiebiorczychkobiet.pl/historia-spk/ (12 listopada 2020).
} 
Z kolei na portalu KobietaPrzedsiębiorcza.com znajduje się wpis z dyskusją na temat: „Czym różni się przedsiębiorczość kobiet od przedsiębiorczości mężczyzn?”, w której padają m.in. następujące stwierdzenia:

(16) Przedsiębiorczość to stan ducha, a nie zawartość portfela. Działanie, poszukiwanie, kreatywne myślenie, współpraca - to właśnie jest przedsiębiorczość! [...] Moim zdaniem „przedsiębiorczość kobiet” różni się znacznie od „przedsiębiorczości mężczyzn”, ale też współpraca tych dwóch „przedsiębiorczości” może dać fantastyczne efekty ekonomiczne. Bierze się to z różnic przynależnych kulturowo każdej z płci ${ }^{30}$.

Jeśli chodzi o nomenklaturę nazewniczą, która pojawia się w analizowanej komunikacji, jej próbkę przedstawiają poniższe fragmenty:

(17) Czy jesteś kobietą przedsiębiorczą? O przedsiębiorczości kobiet pisze się ostatnio bardzo dużo. Kasia Gradek sprawdza, jakimi cechami powinna się wyróżniać kobieta sukcesu ${ }^{31}$.

(18) Cykl debat Wiedza Nie Ma Płci to także zaproszenie do dyskusji o kobietach w biznesie, o tym, czego potrzebują i jak widzą przyszłość, w której patriarchat z wolna chyli się ku upadkowi.

(19) Biznesplan kobiety przedsiębiorczej ${ }^{32}$.

(20) Jak przedsiębiorczynie mogą się odnaleźć w nowej rzeczywistości?33.

(21) Klub Kobiet Przedsiębiorczych to platforma wymiany doświadczeń dla przedsiębiorczyń i kobiet piastujących kierownicze stanowiska ${ }^{34}$.

Znamienne w tym względzie są również nazwy innych niż wspomnianych wyżej stowarzyszeń kobiet związanych z biznesem, przykładowo takie jak: Klub Kobiet Biznesu, Klub Kobiet Przedsiębiorczych, Kobiecy Klub Biznesu, Biznesowy Klub Kobiet, Stowarzyszenie Właścicielek Firm, Akademia Kobiecej Przedsiębiorczości.

Wskazane przykłady to tylko minimalna egzemplifikacja narracji kobiecych środowisk biznesowych, wystarczająca jednak, aby wstępnie zilustrować ich komunikację, której specyfika jest w interesującym nas aspekcie następująca: po pierwsze - wyraźne jest eksponowanie zawodowej samodzielności lub emancypacji kobiet komunikowanej jako unikalnej dla nich przedsiębiorczości. Po drugie - równie mocno jest akcentowana wspólnotowość - solidarność kobiecego dążenia do biznesowej aktywizacji. Po trzecie - biznes jest miarą sukcesu, ale kobiecy sukces może wynikać z działań nie tylko stricte biznesowych, lecz także społecznych, kulturalnych czy naukowych. Takie szerokie ujmowanie kobiecej przedsiębiorczości sprawia, że frazy kobieta przedsiębiorcza i kobieta biznesu (także kobieta $w$ biznesie) zyskują tożsame (lub bardzo bliskie)

${ }^{30}$ Zob. http://kobietaprzedsiebiorcza.com/jak-zyc-godnie-dostatnio-i-zachowac-kobiecosc (30 lipca 2020).

${ }^{31}$ Zob. https://sukcespisanyszminka.pl/czy-jestes-kobieta-przedsiebiorcza/ (4 października 2020).

32 Zob. https://mambiznes.pl/wlasny-biznes/wiadomosci/biznesplan-kobiety-przedsiebiorczej-5678 (30 lipca 2020).

${ }^{33}$ Zob. https://siecprzedsiebiorczychkobiet.pl/jak-przedsiebiorczynie-moga-odnalezc-sie-w-nowej-rzeczywistosci/ (24 marca 2021).

${ }^{34}$ Zob. https://www.klubkp.pl/ (15 lutego 2021). 
znaczenie referencyjne ze znaczeniem syntagmy kobieta sukcesu. W analizowanych narracjach chodzi o sukces rozumiany i mierzony inaczej niż po transformacji z 1989 roku. Obecnie Polki wyrażają go już nie przez pryzmat wymiaru materialnego, demonstrują nie „biznesowość”, ale przedsiębiorczość sensu stricto ${ }^{35}$, a przy tym akcentują niezależność (od męskiego świata biznesu) w swojej aktywności. Jednak zarazem okazują się świadome konieczności funkcjonowania w realiach biznesowych (chociażby tych formalnych) wspólnych dla wszystkich bez względu na płeć, co znajduje odzwierciedlenie w stosowaniu rozmaitej nomenklatury nazewniczej: i tej typowej dla siebie - wyrażanej w analitycznych nazwach, i tej obecnej w całym dyskursie publicznym, chociażby przez stosowanie leksemu bizneswoman w ważnym dla nich konkursie. Cytowania wyborów nazewniczych wskazały też na używanie feminatywum przedsiębiorczyni, czyli wariantu, który w danych korpusowych ujawnia się jako leksem typowy dla komunikacji specjalistycznej. Jego stosowaniu w kobiecych narracjach przyświeca więc idea profesjonalizacji ich dyskursu. Warto dodać, że częstym kontekstem użycia jest dla tej formacji zestawienie mające na celu eksponować równość mężczyzn i kobiet w biznesie: przedsiębiorcy i przedsiębiorczynie ${ }^{36}$.

Z perspektywy środowisk kobiecych nazwy analityczne stają się językowym narzędziem je wyróżniającym, pozwalają skupić uwagę na kobietach i zaznaczyć ich obecność w biznesie, który otworzył się dla nich później niż dla mężczyzn. Zresztą przemiana wzorców zawodowych kobiet i postrzegania ich roli w naszym społeczeństwie nadal się toczy. Przykładowo: organizatorki wspomnianego już plebiscytu „Bizneswoman Roku” stwierdzają, że „biznes nadal w powszechnej świadomości jest domeną męską. Nie jest łatwo być kobietą, matką i bizneswoman"37. Stadium po 2004 roku to faza, którą socjologowie opisują m.in. jako proces zmiany archetypu przypisanego do Polek:

Jak pokazują badania, z każdym rokiem coraz więcej Polek zakłada własną działalność gospodarczą, szukając nowych kierunków rozwoju, dążąc do zmiany ścieżki zawodowej czy poprawy swojej sytuacji ekonomicznej. [...] Widać przy tym stopniową zmianę dominującego wzoru rodziny i częściowe odejście od tradycyjnego modelu związku, w którym głową rodziny i jej głównym żywicielem jest mężczyzna. Wciąż jednak co siódmy mąż/partner przedsiębiorczyni przyznaje, że wolałby, by jego żona/partnerka nie pracowała, lecz zajmowała się domem. Sporo jest więc jeszcze do zrobienia, aby archetypiczna Matka Polka stała się Matką Polką Bizneswoman ${ }^{38}$.

Wprowadzenie do dyskursu środowisk kobiecych frazy kobieta przedsiębiorcza - nowej „etykiety” nazewniczej - oraz eksplikację przedsiębiorczości w tych środowiskach

\footnotetext{
${ }^{35}$ Według SJP PWN przedsiębiorczy to taki, który jest 'chętny do podejmowania różnych spraw i umiejący je pomyślnie załatwić’. Zob. https://sjp.pwn.pl/szukaj/przedsi\%C4\%99biorczo\%C5\%9B\%C4\%87. html (20 stycznia 2021).

${ }^{36}$ Egzemplifikacje tych zestawień można znaleźć np. na stronie Sieci Przedsiębiorczych Kobiet.

${ }^{37}$ Zob. https://bizneswomanroku.pl/chcesz-zostac-bizneswoman-roku/ (11 listopada 2019).

${ }^{38}$ Fragment raportu „Zawód: Prezeska! - diagnoza przedsiębiorczości kobiet” przygotowanego na zlecenie Sieci przedsiębiorczych Kobiet. Zob. http://www.delab.uw.edu.pl/wp-content/uploads/2017/04/ DELabUW_zawod_prezeska.pdf(10 października 2019).
} 
można interpretować jako swoisty akt, zarówno językowej, jak i mentalnej, emancypacji kobiet w zmaskulinizowanym świecie biznesu i wypełniających go biznesmenów. Kobiety chcą i potrafią być aktywne biznesowo (jako kobiety biznesu), ale nie chcą zawężania tej aktywności do działań wyłącznie skupionych na zarabianiu pieniędzy (co nadal jest postrzegane jako domena mężczyzn ${ }^{39}$ ).

Po uwzględnieniu danych z badań korpusowych należy stwierdzić, że prawdopodobną inspiracją do sięgnięcia po omawianą frazę stało się jej użycie jako nazwy własnej wspominanego wcześniej konkursu firmy Avon ${ }^{40}$. Nie jest ona też tak strukturalnie ustabilizowana jak kobieta biznesu czy kobieta sukcesu, co ma dwojaką przyczynę: to jednostka stosunkowo nowa, a poza tym przymiotnikowy charakter określenia stwarza możliwość inwersji do postaci przedsiębiorcza kobieta, która formalnie bliższa jest charakterystyce niż faktycznej nominacji. Jednak potencjał nazewniczy tej frazy oraz jej szersze przenikanie można już zaobserwować w użyciach poza narracjami feministycznymi, np.

(18) Kobiety przedsiębiorcze są wizjonerkami ${ }^{41}$.

(19) Kobieta przedsiębiorcza w czasach pandemii ${ }^{42}$.

(20) Kobieta przedsiębiorcza na obszarach wiejskich ${ }^{43}$.

(21) Być kobietą przedsiębiorczą ${ }^{44}$.

(22) Kobieta przedsiębiorcza w Unii Europejskiej - nowe wyzwania i nowe możliwości ${ }^{45}$.

Kobieta przedsiębiorcza stała się również kluczową frazą w manifeście przedsiębiorczości kobiet ogłoszonym przez jedną z partii politycznych (Nowoczesna), por.: „Kobieta niezależna to kobieta przedsiębiorcza"46.

\section{UWAGI KOŃCOWE}

Jak zauważa Agnieszka Małocha-Krupa, „[...] wszelka wariancja językowa: tekstowa, słowotwórcza, fleksyjna świadczy o żywotności określonej kategorii językowej”

\footnotetext{
${ }^{39}$ Zob. badania przeprowadzone przez Paruzel-Czachurę i Chełkowską (2014).

${ }^{40}$ Więcej informacji na temat tego konkursu zob. http://odpowiedzialnybiznes.pl/dobre-praktyki/kobieta-przedsiebiorcza-avon-cosmetics-polska-2/ (18 października 2018).

${ }^{41}$ Zob. https://businessandprestige.pl/connect-accelerate-kobiety-przedsiebiorcze-wizjonerkami/ (4 września 2019).

${ }^{42}$ Zob. https://www.radiolodz.pl/broadcast_posts/60691-kobieta-przedsiebiorcza-w-czasach-epidemii -strefa-publiczna (25 maja 2020).

${ }^{43} \mathrm{Zob}$. http://www.lgdowocowyszlak.pl/strona-glowna/zaproszenie-na-konferencje-kobieta-przedsiebiorcza-na-obszarach-wiejskich-28-pazdziernika-2020-r (20 listopada 2020).

${ }^{44}$ Zob. https://bezowijania.com/byc-kobieta-przedsiebiorcza (15 marca 2021).

${ }^{45}$ Zob. https://www.arimr.gov.pl/serwis-prasowy/tam-bylismy/artykuly/mazowsze-kobieta-przedsiebiorcza-w-unii-europejskiej-nowe-wyzwania-i-nowe-mozliwosci.html (15 marca 2021).

${ }^{46}$ Zob. https://www.wnp.pl/parlamentarny/spoleczenstwo/nowoczesna-manifest-kobieta-niezalezna-to -kobieta-przedsiebiorcza-chcemy-to-promowac,20138.html (20 listopada 2020).
} 
(2018, 106). Wariantywność nazw kobiet we współczesnym dyskursie publicznym, będąca punktem wyjścia dla przedstawionych badań, w ich świetle zdecydowanie potwierdza cytowaną tezę. Współistnienie licznych alternatywnych jednostek nominacyjnych to - z jednej strony - odzwierciedlenie postępującej i różnokierunkowej adaptacji anglicyzmu businesswoman w polszczyźnie na tle rodzimej tradycji nazewniczej, natomiast $\mathrm{z}$ drugiej - dowód na powiązanie tego procesu $\mathrm{z}$ dyskursywnymi wyborami komunikacyjnymi dotyczącymi stopniowej zawodowej (biznesowej) emancypacji Polek najpierw po 1989, a następnie po 2004 roku.

Z perspektywy systemu językowego analizowana wariantywność nazewnicza dokumentuje wieloetapowy proces adaptacji terminu businesswoman i związane z tym mechanizmy, które miały (i mają nadal) wpływ na wybory nazewnicze w kontekście rodzimej tradycji. Losy adaptacji wskazanego anglicyzmu rozpoczynają się od etapu importacji (zapożyczenia właściwego) ${ }^{47}$, po czym obserwujemy jego częściową adaptację do wariantu bizneswoman. Zaletą obu jednostek jest ich postać, pojemna znaczeniowo i ekonomiczna, ale na ich niekorzyść przemawia brak fleksyjności, w tym - problem $\mathrm{z}$ decyzją co do formy w liczbie mnogiej (dwie bizneswoman czy dwie bizneswomen?). O bardziej zaawansowanym etapie spolszczenia świadczy feminatyw biznesmenka, który poddano adaptacji słowotwórczej poprzez sufiks reprezentatywny dla polskiego systemu nazewniczego kobiet - walorami tej jednostki są zarówno systemowa regularność, jak i ekonomiczność, ważna zwłaszcza w języku potocznym (por. sportsmenka). Frazy będące formalnie kalkami strukturalno-semantycznymi kobieta biznesu oraz kobieta interesu są dłuższe, mają postać dwuelementowych zestawień, przy czym druga z nich ma znacznie niższą frekwencję wystąpień prawdopodobnie $\mathrm{z}$ uwagi na cechującą ją stylistyczną „,szorstkość”. Wydaje się, że struktura tych kalk dała formalną podstawę do bardziej polsko brzmiącej syntagmy kobieta przedsiębiorcza.

$\mathrm{W}$ obecnych realiach, kiedy obserwujemy zjawisko silnie zaznaczające się społecznie i komunikacyjnie, jakim jest „biznes w kobiecych rękach”48, przedstawione mechanizmy językowe są sprzężone z narracjami opisującymi to zjawisko. Środowiska kobiece celowo poszukują nazw, które okażą się najbardziej adekwatne do specyfiki własnych aktywności w biznesie i w pełni wyczerpujące referencyjnie. Kluczowe w tych poszukiwaniach rozumienie przedsiębiorczości staje się tu pewnym strumieniem dla dyskursów feministycznych, skoro odsłania się w nim świadomość kobiet co do ich samostanowienia w sferze aktywności zawodowej (tu - konkretnie w działaniach biznesowych), co z kolei przejawia się w demonstrowaniu wyborów na poziomie nominacji. Owe wybory ujawniają być może w kobiecych praktykach komunikacyjnych kiełkujący rodzaj władzy społecznej, którą Michael Fleischer nazwał władzą interpretacyjną. Jak stwierdził badacz:

\footnotetext{
${ }^{47}$ W zakresie ustaleń dotyczących zapożyczeń korzystam z publikacji: Dunaj (1993) i Witalisz (2016).

${ }^{48}$ Por. „Biznes w Kobiecych Rękach” - kompleksowy program akceleracyjny adresowany do kobiet, które mają pomysł na biznes i są gotowe założyć swoją firmę w trakcie trwania programu”. https://siecprzedsiebiorczychkobiet.pl/biznes-w-kobiecych-rekach/ (15 listopada 2020).
} 
[K]to dysponuje władzą interpretacyjną, wyznacza kierunek i sposób komunikowania na dany temat. Kto pierwszy przeforsuje swoje wyznaczniki interpretacji zjawisk, ten kieruje dyskursem publicznym, a pozostali uczestnicy procesu muszą i mogą się już tylko odnosić do stojących do dyspozycji ram interpretacyjnych [...] (Fleischer 2014, 147).

Koncepcja zrodzenia się takiej władzy interpretacyjnej koreluje w przeprowadzonych badaniach z wynikami kwerend słownikowych i korpusowych, wykazującymi dominację feminatywów bizneswoman, biznesmenka oraz syntagmy kobieta biznesu we współczesnym dyskursie publicznym, jak również odmienne preferencje dyskursów środowisk kobiecych. W ich komunikacji, akceptującej wygodną (bo ekonomiczną) i „oswojoną” w polszczyźnie bizneswoman, a także - symetryczną wobec przedsiębiorcy - przedsiębiorczynię, wyrazisty jest wybór konstrukcji analitycznych, w tym wprowadzanie frazy kobieta przedsiębiorcza, z wartością referencyjną bliską eksplikacji kobiety sukcesu. Kobieta przedsiębiorcza jest więc jednostką dogodną i systemowo (spełnia kryterium fleksyjne), i semantycznie (wyraża istotę zjawiska). Ten wariant nazewniczy na razie odnajduje swoją sferę aktualizacji przede wszystkim w narracjach dyskursów feministycznych, trudno jednak przewidzieć, czy jego ramy interpretacyjne nie zostaną też przeniesione do szerszej przestrzeni dyskursu publicznego, skoro mamy już pierwsze tego zwiastuny.

\section{BIBLIOGRAFIA}

Arabski, J., red. 1997. Języki specjalistyczne. Język biznesu. Katowice: Wyższa Szkoła Zarządzania Marketingowego i Języków Obcych.

Balczyńska-Kosman, A. 2011. „Udział kobiet w mediach a problematyka stereotypów płci”. Przegląd Politologiczny 2: 113-120.

Cudak, R., i J. Tambor. 1996. „Czy istnieje polski język biznesu?”. Acta Universitatis Lodziensis. Kształcenie Specjalistyczne Cudzoziemców 7/8: 109-120.

Dominiak, A. 2001. „Profile pojęć: ‘biznes’, ‘biznesik', ‘biznesmen' i ‘bizneswoman’ we współczesnym języku polskim". Poradnik Językowy 8: 9-27.

Dunaj, B. 1993. „Żeńskie odpowiedniki wyrazu biznesmen: businesswoman, kobieta interesu, biznesmenka itp.”. Język Polski 73 (3): 167-172.

Fleischer, M. 2014. Kapital - niestety nie()ludzki. Kraków: Wydawnictwo Libron.

Gajda, P. 2015. „Cechy polskiego języka biznesu jako języka specjalistycznego w początkowym etapie kształtowania się (na podstawie «Czasu» z lat 1870-1914)". Investigationes Linguisticae 33: 43-54. Grybosiowa, A. 2001. „Biznesmeni czy nowi kapitaliści?”. Poradnik Językowy 9: 66-69.

Grzeszczyk, E. 2003. Sukces. Amerykańskie wzory - polskie realia. Warszawa: Wydawnictwo Instytutu Filozofii i Socjologii Polskiej Akademii Nauk.

Hącia, A. 2010. „O bezpieczeństwie i niebezpieczeństwach języka firm ubezpieczeniowych”. W Polskie języki. O językach zawodowych i środowiskowych. Materiały VII Forum Kultury Stowa, red. M. Milewska-Stawiany, i E. Rogowska-Cybulska. Gdańsk: Wydawnictwo Uniwersytetu Gdańskiego, 201-218. 
Karwatowska, M., i J. Szpyra-Kozłowska. 2005. Lingwistyka ptci. On i ona w języku polskim. Lublin: Wydawnictwo Uniwersytetu Marii Curie-Skłodowskiej.

Kochan, M. 2010. „Mówiony język biznesu”. W Polskie języki. O językach zawodowych i środowiskowych. Materiaty VII Forum Kultury Stowa, red. M. Milewska-Stawiany, i E. Rogowska-Cybulska. Gdańsk: Wydawnictwo Uniwersytetu Gdańskiego, 140-175.

Kwiatkowski, M. 2000. Człowiek sukcesu ekonomicznego jako wzór osobowy w pierwszych latach transformacji systemowej w Polsce. Studium z socjologii moralności. Zielona Góra: Lubuskie Towarzystwo Naukowe.

Łaziński, M. 2006. O panach i paniach. Polskie rzeczowniki tytularne i ich asymetria rodzajowo-ptciowa. Warszawa: Wydawnictwo Naukowe PWN.

Małocha-Krupa, A., red. 2015. Słownik nazw żeńskich polszczyzny. Wrocław: Wydawnictwo Uniwersytetu Wrocławskiego.

Małocha-Krupa, A. 2018. Feminatywum w uwikłaniach językowo-kulturowych. Wrocław: Oficyna Wydawnicza ATUT - Wrocławskie Wydawnictwo Oświatowe.

Mandal, E. 1994. „Businesswoman - nowy wzorzec kobiecości”. Kobieta i Biznes: akademicko-gospodarcze forum 4: 1-3.

Mandal, E., A. Gawor, i J. Buczny. 2012. „The stereotypes of man and woman in in Poland - content and factor structures". W Masculinity and femininity in everyday life, red. E. Mandal. Katowice: Wydawnictwo Uniwersytetu Śląskiego, 11-23.

Nowosad-Bakalarczyk, M. 2009. Płeć a rodzaj gramatyczny we współczesnej polszczyźnie. Lublin: Wydawnictwo UMCS.

Paruzel-Czachura, M., i M. Chełkowska. 2014. „Damski i męski świat biznesu - merkantylizm psychiczny oraz percepcja kryzysu ekonomicznego i własnego sukcesu”. Kobieta i Biznes: akademicko-gospodarcze forum 1: 5-15.

Piwowar, J. 2007-2008. „Charakterystyka niektórych przemian funkcjonalnych i frekwencyjnych współczesnej leksyki polskiej”. Zeszyty Naukowe Instytutu Dziennikarstwa i Komunikacji Społecznej UWM 3-4: 158-165.

Witalisz, A. 2016. Przewodnik po anglicyzmach w języku polskim. Kraków: Wydawnictwo JAK.

Wolny-Peirs, M. 2005. Język sukcesu we wspótczesnej polskiej komunikacji publicznej. Warszawa: Wydawnictwo Trio.

\section{WYKAZ ŹRÓDEL}

Klub Kobiet Przedsiębiorczych. https://www.klubkp.pl/ (15 lutego 2021).

Kobieta Przedsiębiorcza.com. http://kobietaprzedsiebiorcza.com/ (30 lipca 2020).

Monco: wyszukiwarka korpusowa dla tekstów publikowanych w polskich portalach internetowych. www. mocno.frazeo.pl (20 marca 2021).

NKJP: Narodowy Korpus Języka Polskiego. www.nkjp.pl (4 października 2020).

NSP 1985-1982: Nowe stownictwo polskie. Materialy z prasy z lat 1985-1982, red. T. Smółkowa, cz. 1-2. Kraków 1998-1999.

NSP 1993-2000: Nowe stownictwo polskie. Materialy z prasy z lat 1993-2000, red. T. Smółkowa, cz. 1-4.

Kraków 2004-2006. 
NSP 2001-2005: Nowe stownictwo polskie. Materiaty z prasy z lat 2001-2005, red. T. Smółkowa, cz. 1-6.

Kraków 2010-2015.

Przedsiębiorcza. https://przedsiebiorcza.com/ (30 lipca 2020).

PWC. https://www.pwc.pl/pl/o-nas/kobiety.html (30 lipca 2020).

Sieć Przedsiębiorczych Kobiet. https://siecprzedsiebiorczychkobiet.pl/ (12 listopada 2020).

SJP PWN: Stownik języka polskiego. www.sjp.pwn.pl (20 października 2019).

Słowosieć. http://plwordnet.pwr.wroc.pl/wordnet/ (20 października 2019).

Sukces Pisany Szminką. https://sukcespisanyszminka.pl/ (4 października 2020).

SW: Karłowicz J., A. Kryński, i W. Niedźwiedzki. 1900-1927. Słownik języka polskiego, t. 1-8. Warszawa (tzw. Słownik warszawski).

WSJP: Żmigrodzki, P., red. 2007-. Wielki słownik języka polskiego. Kraków: Instytut Języka Polskiego

Polskiej Akademii Nauk. http://www.wsjp.pl (20 października 2019).

\title{
Bizneswoman, biznesmenka, kobieta biznesu, przedsiębiorczyni or kobieta przedsiębiorcza? Naming Conventions Observed in Contemporary Public Discourse Relating to Women Engaged in Business Activities
}

Keywords: personal feminine forms, feminatywum, anglicism, women in business, public discourse, appelative trends.

\begin{abstract}
The subject of the article is the analysis of the variants of nomenclature in contemporary public discourse relating to women engaged in business activities. The aim of the analyzes is to explain the conditions of the existing variance in the linguistic (systemic and stylistic) and extra-linguistic (political, social and cultural) perspective. The research on the contexts of the functioning of the analyzed units was carried out on the material obtained from dictionary-corpus queries and own excerption. Due to the discursive implication of personal female names, the communication narratives of women's communities were subject to separate verification. The presented discussion allows for the following conclusions: 1) the variability of the analyzed nominations present in the public discourse is the result of changes in language and communication determined by cultural and social factors after the turn of the ' 89 and next Poland's accession to the UE; 2) the existing nomenclature alternatives are the result of the process of adapting anglicism businesswoman in the Polish language, with simultaneous competition from native forms, and interweaving these phenomena with changes in the communication of female business communities; 3) the nomenclature choices have stylistic and discursive justification; 4) the newest unit in the study, kobieta przedsiębiorcza, becomes one of the linguistic manifestations of the professional emancipation of Polish women.
\end{abstract}

